\title{
LOS ENSAYOS DEL ENSAYO
}

Sobre Alberto Giordano (Ed.). El discurso sobre el ensayo en la cultura argentina desde los 80. Buenos Aires: Santiago Arcos, 2015, 250 pp.

Javier Rossanigo

UNR

Una primera lectura de El discurso sobre el ensayo en la cultura argentina desde los 80 apareció firmada, en un periódico porteño, por un reconocido crítico y editor literario. Allí, le toca al libro lidiar con el equívoco. No por malicia del autor del comentario sino por un error que podría considerarse casi de tipeo si no fuera porque, aún a su pesar, contribuye a confundir en parte el espíritu que atraviesa el libro. Al transcribir su título, en el artículo se produce un desplazamiento de la preposición "desde" hacia su homóloga categorial "de", corriéndose así el riesgo de leerlo como una foto del estado del ensayo en la década del 80 en lugar de ser atendido como un recorrido por las intervenciones que vienen suscitándose desde entonces en torno al género. Estas intervenciones son recuperadas en esta antología al modo de "archivo de un proceso" que, iniciado en los 80 con la publicación de artículos, dossiers, libros y la realización de encuentros, se prolonga hasta el comienzo del nuevo milenio, cuando finalmente la forma ensayística conquista cierta legitimación como alternativa polémica del conocer y logra convivir, desde entonces, en permanente tensión con otros discursos del saber embargados por la burocratización académica. 
Esto queda bien explicitado en el estudio con que Giordano abre el libro, donde luego de arriesgar un acercamiento a la definición de ensayo como "una tentativa de articular, a través de la experimentación con formas argumentativas, la particularidad -en el límite, intransferible- de las experiencias lectoras con la generalidad conceptual de los saberes interpelados por la narración de esa experiencia", se propone trazar el periplo de la tradición ensayística argentina. "Obliterada" en los 60 cuando la "teoría" "habría impuesto las supersticiones de la especificidad y la especialización, como condiciones de conocimiento verdadero, en el campo de las humanidades y las ciencias sociales", esta tradición habría logrado sobrevivir a los ataques que los nuevos aires de los estudios culturales argentinos le propinaban, gracias al peso específico de nombres propios como el de Borges, Martínez Estrada, Masotta o Viñas y a la fuerza gravitacional de sus obras, para volver a irrumpir a mediados de los 80 , en la voz de un puñado de críticos interesados por recomponer el vínculo portentoso entre saber y escritura que la profesionalización académica desdeñó en pos de una relación funcional que subordina el segundo de los términos a los 'a priori' del primero.

En este (re)comienzo del discurso sobre el ensayo el disenso se torna constitutivo y señala un desdoblamiento que lo motoriza hasta la actualidad. Por un lado, dice Giordano, despierta adhesiones el discurso sobre el ensayo como "búsqueda de inteligibilidad", esta perspectiva "responde a la voluntad de apropiarse de la plasticidad de sus retóricas para sumarle a la cultura intelectual un recurso persuasivo", por otro lado, se vigoriza la defensa del ensayo " como experiencia irónica de los límites de lo comunicable" que suscita "la invención de estilos críticos modelados por lo intransferible de 
las experiencias individuales, formas disuasorias de resistir los compromisos que tramitan las seducciones humanistas".

Las líneas internas del libro están tensadas por esta diferencia. Sarlo, un poco en solitario en el contexto de los demás artículos, se erige con su intervención "La crítica: entre la literatura y el público" como la portavoz de quienes ven en las retóricas del ensayo un modo de escapar de la "jerga" academicista que convirtió al lenguaje de la crítica en un "discurso para iniciados" y de producir un acercamiento con un público culto más amplio que, aunque ahuyentado últimamente por la endogamia académica, supo acusar, tal como lo evidencian anteriores episodios de la cultura argentina, el recibimiento de obras de ensayistas como Martínez Estrada.

"Para Sarlo, la escritura del ensayo no es en sí misma un problema" dice Giordano, y agrega en nota al pie "contra este imaginario funcionalista se enuncia la máxima: 'no escribir sobre ningún problema, si ese escribir no se constituye también en problema". La cita la toma de "Elogio del ensayo", magistral artículo con que Horacio González colabora en el libro. En esta intervención datada en 1990 el ex director de la Biblioteca Nacional refuerza este motivo de la escritura como problema en sí con una sentencia que no oculta su cuota de lirismo: en el ensayo se asume "un modo de escribir que debe dejar el resuello del pensamiento sobre el lenguaje".

De esta forma, con González a la cabeza, las discusiones acerca de las especificidades del ensayo como género van a atender con predilección las problemáticas en torno a la relación sujeto/escritura/saber, entendiendo que allí se cifra quizá la especificidad última del ensayo, su valor diferencial respecto a las formas hegemónicas del discurso. 
Así, por ejemplo, Nicolás Casullo en su artículo "Entre las débiles estridencias del lenguaje" señala que usufructuada únicamente como mediación funcional "la palabra ha devenido experiencia de desmemoria", logrando así que el lenguaje quede "exiliado de su travesía como conocimiento". Ante este panorama que para Casullo es propio de la modernidad, de "la saturación y la fractura cultural que atravesamos", vale salir al rescate de "la posibilidad de otro ensayar con la palabra en las afueras del magno texto de la utopía tecno científica cumplida: fugar de dichos textos leyes, "excavar como un arqueólogo" en busca de objetos, señales, indicios, que quedaron como débiles estridencias detrás de las consagraciones discursivas".

A su turno, en "Melodías, sonetos, papers", Christian Ferrer abre su intervención con un polémico pensamiento contrafáctico al especular con que "todo podría haber sido de otra manera si las ciencias sociales originarias hubieran preferido, como modelo prototípico de legitimación, al arte en lugar de las ciencias exactas" y propone para los estudios culturales un corrimiento del "majestuoso 'Nosotros' del discurso científico" hacia un lugar de enunciación que asuma "la ambigüedad de lo existente" y hable "en nombre propio". Claro que este "hablar en nombre propio" debe tener sus contenciones y Ferrer se apresura a alertar que el "abuso de esa primera persona engendraría: la vanidad autobiográfica o fetichizar el apellido para integrarse a espacios de consagración intelectual". Una advertencia que se reitera con pertinencia en otros artículos del libro y que busca poner diques a quienes pretendan entrar al ensayo en busca de una coartada que les permita, en nombre del subjetivismo, sortear la preparación necesaria que hoy en día los campos de las ciencias sociales exigen.

Son varios los artículos que integran El discurso sobre el ensayo en la cultura argentina desde los 80 que insisten, con énfasis 
diferentes, en postular la predisposición ensayística como un modo de espabilar al discurso académico acerca de sus pretensiones de dar con una verdad definitiva y no advertir que en ese movimiento suele quedar encorsetado en sus propios esquematismos. En un artículo que desmenuza al detalle la cuestión de la subjetividad en la escritura, Carlos Kuri advierte que el ensayo no pretende "la postulación de "otro" saber", lo que se persigue es "la eficacia del saber al constituirse de un modo "ladeado", en fricción con la razón como Orden".

Hoy día y desde hace ya más de un siglo, cuando el positivismo vino a imponer el tutelaje de La razón sobre la búsqueda del conocimiento, quienes ejercen el poder de policía sobre el saber suelen desdeñar los proyectos subjetivos que, rumiando el pensamiento a dentelladas de escritura, buscan trazar otro camino en su consecución del saber. Hacia ellos disparan sus dardos los defensores del ensayo. Pero no al modo de Bianco, el taimado parapsicólogo que compone Saer en La ocasión, quien pretende desarticular el andamiaje de los positivistas sin conocerlo y sin otra refutación a su alcance que su sedicente poder de alterar el estado de la materia con el voluntarismo de sus pensamientos. Al contrario, asumiendo las limitaciones que no quiere advertir esa forma del conocer, los defensores del ensayo vienen a reencauzar una discusión que estuvo acallada en el panorama cultural vernáculo, a pesar de las grandes obras que testimonian la pertinencia ensayística, y a proponer este género como un modo de acceder a formas de conocimientos que hoy permanecen vedadas por las limitaciones inherentes a los discursos que hegemonizan la reproducción académica en el campo de las humanidades y de las ciencias sociales. 